\title{
Long Period Starvation in Rat: the Effect of Aloe Vera Gel Extract on Oxidative Stress Status \\ ORIGINAL
}

Laleh Shahraki Mojahed", Mehdi Saeb',

Mohammad Mohsen

Mohammadi',

Saeed Nazifi

\section{Abstract}

Objective: Starvation have pro-oxidative effect as a consequence of both elevated ROS generation and defeat in neutralization of ROS. Aloe vera juice induced oxidative stress and significantly decreased antioxidant enzymes levels. The main aim of this experiment was to evaluate the effect of Aloe vera gel extract on oxidative stress status during long period starvation.

Method: Twenty-four mature male albino Wistar rats were housed in standard cages. In this study starvation cycle (rats were starved for two days and then were fed for one day) was used. This study was performed during long period (60 days).Animals were divided into four experimental groups (six rats in each group): 1) normal control; 2) starved rats + water/ethanol; 3) starved rats + hydro-alcoholic Aloe vera gel extract $(100 \mathrm{mg} / \mathrm{kg})$; 4) starved rats + hydro-alcoholic Aloe vera gel extract $(200 \mathrm{mg} / \mathrm{kg}) ; 5)$ Without starvation with hydro-alcoholic Aloe Vera gel extract $(100 \mathrm{mg} / \mathrm{kg}) ; 6)$ Without starvation with hydro-alcoholic Aloe Vera gel extract $(200 \mathrm{mg} / \mathrm{kg}$ ). Blood samples were obtained using cardiac puncture. In blood samples, antioxidant enzymes including SOD, GPx and catalase, antioxidant trace elements including copper, zinc and manganese and antioxidant vitamins including vitamin $A$, vitamin $E$ and vitamin $C$ were measured.

Results: Plasma levels of antioxidant enzymes (SOD, GPX and catalase) significantly decreased in starved rats + water/ethanol group $(P<0.05)$. Plasma levels of antioxidant enzymes after treatment with hydro-alcoholic Aloe vera gel extract at doses 100 and 200 mg/kg were significantly increased $(P<0.05)$. Also, plasma levels of antioxidant enzymes in normal rats (without starvation) after treatment with hydro-alcoholic Aloe vera gel extract at doses 100 and $200 \mathrm{mg} / \mathrm{kg}$ were significantly increased $(P<0.05)$. Plasma levels of $\mathrm{Cu}, \mathrm{Zn}$ and 
Mn in normal control group had no significant difference with starved rats + water/ethanol and starved rats + hydro-alcoholic Aloe vera gel extract in 100 and $200 \mathrm{mg} / \mathrm{kg}$ dose groups ( $P>0.05$ ). Plasma levels of vitamin $A$ and $E$ in normal control group had no significant difference with starved rats + water/ethanol and starved rats + hydro-alcoholic Aloe vera gel extract in the 100 and $200 \mathrm{mg} / \mathrm{kg}$ dose groups $(P>$ 0.05). Plasma level of vitamin $C$ significantly decreased in starved rats + water/ethanol group $(P<0.05)$. Plasma level of vitamin $C$ after treatment with hydro-alcoholic Aloe vera gel extract at doses 100 and $200 \mathrm{mg} / \mathrm{kg}$ was significantly increased $(P<0.05)$. Also, plasma level of vitamin $C$ in normal rats (without starvation) after treatment with hydro-alcoholic Aloe vera gel extract at doses 100 and 200 mg/kg was significantly increased $(P<0.05)$.

Conclusion: Our results shown that long period starvation caused an increase in oxidative stress via impairing of antioxidant defense and Aloe vera treatment is able to improve antioxidative defense induced by long period starvation.

\section{Keywords}

Aloe Vera Gel Extract;

Oxidative Stress; Long Period Starvation; Rat.

\section{Introduction}

Oxidative stress results in imbalance between reactive oxygen species (ROS) generation and cellular antioxidant defense. Oxidative stress contributes to pathogenesis of some diseases as well as ageing process [1]. Various factors such as environmental, dietary factors and diseases affect stress oxidative level in body [1, 2]. Defense against oxidative stress, antioxidant defense, has different components involving enzymatic and non-enzymatic antioxidant defense. Enzymatic antioxidant defense includes superoxide dismutase (SOD), glutathione peroxidase (GPX), catalase (CAT). Non-enzymatic antioxidants include ascorbic acid (vitamin C), tocopherol (Vitamin E), glutathione (GSH), carotenoids, flavonoids, and other antioxidants [1].

Starvation or food deprivation caused metabolic changes in body. Starvation decreased glucose plasma level. Lipid oxidation increased [3, 4] or was not changed [5] during starvation. Starvation has been reported to have pro-oxidative effect as a consequence of both elevated ROS generation and defeat in neutralization of $\operatorname{ROS}[6,7,8,9]$. However, one study has reported starvation was not associated with increased oxidative stress in mallards [10].

Recently, attention has been focused on herbal medicines which have antioxidant activities to prevent and protect oxidative damage caused by free radical species [11]. Aloe vera is a species of Aloe that belongs to Liliaceae family. This plant mainly grows in subtropical and tropical climates [12]. Aloe vera contains different substances and is widely used for a variety of medicinal purposes. Many biological and medicinal properties of Aloe vera are associated with inner gel of the leaves. Several studies have focused on antioxidant effect of Aloe vera [13, 14, 15, 16, 17]. However, one study showed Aloe vera juice induced oxidative stress and significantly decreased antioxidant enzymes levels [18]. 
There is no information about the effect of Aloe vera on starvation. The present study was undertaken to evaluate the effect of Aloe vera gel extract on oxidative stress status during long period starvation. For this purpose, antioxidant enzyme activities including SOD, GPx and catalase, antioxidant trace elements including copper, zinc and manganese and antioxidant vitamins including vitamin A, vitamin $\mathrm{E}$ and vitamin $\mathrm{C}$ were evaluated.

\section{Methods}

\section{Hydro-alcoholic Aloe vera gel extract}

Aloe vera gel powder was provided from Anamis Aloe vera Company. Then, the gel powder (100 g) was added to $500 \mathrm{ml}$ ethanol $70 \%$. The obtained solution was left in the percolator at room temperature for $72 \mathrm{~h}$. Afterwards the solvent was completely removed from the hydroalcoholic extracts by Rota vapor at $40{ }^{\circ} \mathrm{C}$ and dried in a vacuum desiccator.

\section{Animal ethics}

This experiment was accomplished under the approval of the State Committee on Animal Ethics, Shiraz University, Shiraz, Iran. The recommendations of European Council Directive (86/609/EC) of November 24, 1986, regarding the standards in the protection of animals used for experimental purposes were also followed.

\section{Experimental design}

Twenty-four mature male albino Wistar rats, ranging in age from 3 to 4 weeks and weighing 190$220 \mathrm{~g}$ were housed in standard cages. Animals were maintained under temperature control $(23 \pm 1)$ with a 12:12 h light-dark cycle. In this study, starvation cycle (rats were starved for two days and then were fed for one day) was used. This study was performed during an long period (60 days).The animals were divided into four experimental groups (six rats in each group): 1) normal control; 2) starved rats
+ water/ethanol; 3) starved rats + hydro-alcoholic Aloe vera gel extract (100 mg/kg); 4) starved rats + hydro-alcoholic Aloevera gel extract $(200 \mathrm{mg} / \mathrm{kg})$ ); 5) Without starvation with hydro-alcoholic Aloe vera gel extract $(100 \mathrm{mg} / \mathrm{kg}) ; 6)$ Without starvation with hydro-alcoholic Aloe vera gel extract $(200 \mathrm{mg} /$ $\mathrm{kg}$ ). Aloe vera gel extract and different treatments administrated orally. At the end of experiment, rats were anesthetized with ketamin and acepromazine. Blood samples were obtained using cardiac puncture. $1.5 \mathrm{ml}$ of blood was collected in heparinized tubes and used for hemolysate preparation. $2.5 \mathrm{ml}$ of blood was collected in simple tubes and their serum separated by centrifuging at $750 \mathrm{~g}$ for 15 minutes and stored at $-20^{\circ} \mathrm{C}$ for the subsequent assays.

\section{Hemolysate preparation}

Whole blood $(0.5 \mathrm{ml})$ was centrifuged at $750 \mathrm{~g}$ for $15 \mathrm{~min}$. The plasma was aspirated off, and the erythrocyte pellet was washed three times with normal saline solution, and then distilled water was slowly added up to $2 \mathrm{ml}$. The biochemical tests were performed immediately after preparing the hemolysate.

\section{Biochemical assays \\ Antioxidant enzyme activities measurement}

The SOD activity was measured with commercial kit (RANSOD kit, Randox Com, UK). This method employs xanthine and xanthine oxidase to generate superoxide radicals, which react with 2-(4-iodophenyl)3-(4-nitrophenol)- 5-phenyltetrazolium chloride to form a red formazan dye. The enzyme activity was measured by the degree of inhibition of this reaction. GPx activity was measured calorimetrically by Commercial kit (RANSEL kit, Randox Com, UK) based on the method of Paglia and Valentine [19]. The activity of catalase (CAT) was determined with the commercial catalase assay kit (Oxford Biomedical Research, Inc., USA), based on the colorimetric method described by Slaughter and O'Brien [20], which determines the power of enzyme to the di- 
sappearance of $\mathrm{H}_{2} \mathrm{O}_{2}$ at $520 \mathrm{~nm}$. The activities of the enzymes were expressed as U/g of hemoglobin. Hemoglobin concentration was measured by cyanmethemoglobin method.

\section{Trace elements measurement}

The samples with hemolysis were discarded. Digestion of serum was performed by a mixture of perchloric and nitric acid (3:7 ratios respectively). Copper, zinc and manganese were measured using an atomic absorption spectrophotometer (Shimadzo AA-670, Kyoto, Japan). Argon was used as the purging gas. The background absorption was automatically corrected by the Zeeman Effect. One thousand micrograms per milliliter standard solution of each mineral was used in the measurements.

\section{Antioxidant vitamins}

The concentrations of vitamins $A, E$ and $C$ were evaluated by application of the HPLC method using Ultraviolet detection. Vitamins $A$ and $E$ were measured based on the protocol described by JohnsonDavis et al. [21] and vitamin C by a Commercial Kit (ALPCO Diagnostics, USA). The HPLC system used consisted of a solvent delivery pump (JASCO 980-
PU, Tokyo, Japan), a reversed-phase column (Luna (18, 250×4.6 mm; Phenomenex, (A, USA), and a UV-Vis detector (Jasco, UV- 975, Tokyo, Japan).

\section{Statistical analysis}

All Statistical analyses were carried out using SPSS software (version 22). All data were presented as mean \pm S.E. One-way ANOVA was used to test differences between various groups means followed by post hoc Tukey-HSD test. Significant level was less than 0.05 .

\section{Results}

Blood levels of antioxidant enzymes are shown in Table 1. Plasma levels of antioxidant enzymes (SOD, GPX and catalase) significantly decreased in starved rats + water/ethanol group $(P<0.05)$. Plasma levels of antioxidant enzymes after treatment with hydroalcoholic Aloe vera gel extract at doses 100 and $200 \mathrm{mg} / \mathrm{kg}$ were significantly increased $(P<0.05)$. Also, plasma levels of antioxidant enzymes in normal rats (without starvation) after treatment with hydroalcoholic Aloe vera gel extract at doses 100 and 200 $\mathrm{mg} / \mathrm{kg}$ were significantly increased $(P<0.05)$.

Table 1. Blood levels of antioxidant enzymes in different experimental groups during long period starvation of Wistar rats.

\begin{tabular}{|c|c|c|c|}
\hline \multirow{3}{*}{ Groups } & \multicolumn{3}{|c|}{ Antioxidant enzymes } \\
\hline & SOD & GSH-PX & Catalase \\
\hline & U/g of hemoglobin & U/g of hemoglobin & U/g of hemoglobin \\
\hline Normal control & $04.87 \pm 4.07^{a}$ & $1855.9 \pm 94.65^{a}$ & $1.97 \pm 0.06 a$ \\
\hline Starved rats + water/ethanol & $42.21 \pm 2.35^{b}$ & $896.85 \pm 101.06 b$ & $0.77 \pm 0.05 b$ \\
\hline $\begin{array}{l}\text { Starved rats + hydro-alcoholic Aloe Vera gel extract } \\
(100 \mathrm{mg} / \mathrm{kg})\end{array}$ & $62.54 \pm 4.18^{c}$ & $1342.74 \pm 65.58^{c}$ & $1.29 \pm 0.08^{c}$ \\
\hline $\begin{array}{l}\text { Starved rats + hydro-alcoholic Aloe Vera gel extract } \\
(200 \mathrm{mg} / \mathrm{kg})\end{array}$ & $61.22 \pm 4.48^{c}$ & $1413.30 \pm 57.64 c$ & $1.25 \pm 0.04^{c}$ \\
\hline $\begin{array}{l}\text { Without starvation with hydro-alcoholic Aloe Vera gel } \\
\text { extract }(100 \mathrm{mg} / \mathrm{kg})\end{array}$ & $127.14 \pm 4.43^{d}$ & $2283.40 \pm 90.55 d$ & $2.28 \pm 0.05^{d}$ \\
\hline $\begin{array}{l}\text { Without starvation with hydro-alcoholic Aloe Vera gel } \\
\text { extract }(200 \mathrm{mg} / \mathrm{kg})\end{array}$ & $122.98 \pm 4.08^{d}$ & $2313.30 \pm 77.51 d$ & $2.31 \pm 0.07 d$ \\
\hline
\end{tabular}


Table 2. Blood levels of antioxidant enzymes in different experimental groups during long period starvation of Wistar rats.

\begin{tabular}{|c|c|c|c|}
\hline \multirow{3}{*}{ Groups } & \multicolumn{3}{|c|}{ Trace elements } \\
\hline & $\mathrm{Cu}$ & $\mathrm{Zn}$ & Mn \\
\hline & $(\mu \mathrm{mol} / \mathrm{l})$ & $(\mu \mathrm{mol} / \mathrm{l})$ & $(\mu \mathrm{mol} / \mathrm{l})$ \\
\hline Normal control & $1.19 \pm 0.05^{a}$ & $0.81 \pm 0.02$ a & $0.021 \pm 0.004^{a}$ \\
\hline Starved rats + water/ethanol & $1.33 \pm 0.09^{a}$ & $0.71 \pm 0.01$ & $0.027 \pm .006^{a}$ \\
\hline Starved rats + hydro-alcoholic Aloe Vera gel extract (100 mg/kg) & $1.25 \pm 0.07^{a}$ & $0.69 \pm 0.03^{a}$ & $0.022 \pm 0.002^{a}$ \\
\hline Starved rats + hydro-alcoholic Aloe Vera gel extract (200 mg/kg) & $1.23 \pm 0.08^{a}$ & $0.69 \pm 0.01 \mathrm{a}$ & $0.026 \pm 0.003^{a}$ \\
\hline $\begin{array}{l}\text { Without starvation with hydro-alcoholic Aloe Vera gel extract } \\
(100 \mathrm{mg} / \mathrm{kg})\end{array}$ & $1.28 \pm 0.05^{a}$ & $0.82 \pm 0.02^{a}$ & $0.028 \pm 0.002^{a}$ \\
\hline $\begin{array}{l}\text { Without starvation with hydro-alcoholic Aloe Vera gel extract } \\
(200 \mathrm{mg} / \mathrm{kg})\end{array}$ & $1.31 \pm 0.09 a$ & $0.73 \pm 0.02^{a}$ & $0.027 \pm 0.007^{a}$ \\
\hline
\end{tabular}

Different letters indicate statistically significant differences $(P<0.05)$

Table 3. Blood levels of antioxidant enzymes in different experimental groups during long period starvation of Wistar rats.

\begin{tabular}{|c|c|c|c|}
\hline \multirow{3}{*}{ Groups } & \multicolumn{3}{|c|}{ Vitamins } \\
\hline & Vit A & Vit E & Vit C \\
\hline & $(\mu \mathrm{g} / \mathrm{ml})$ & $(\mu \mathrm{g} / \mathrm{ml})$ & $(\mu \mathrm{g} / \mathrm{ml})$ \\
\hline Normal control & $0.23 \pm 0.02^{a}$ & $0.014 \pm 0.002^{a}$ & $29.04 \pm 5.17 \mathrm{a}$ \\
\hline Starved rats + water/ethanol & $0.26 \pm 0.01 a$ & $0.019 \pm 0.001 \mathrm{a}$ & $20.16 \pm 4.38^{b}$ \\
\hline Starved rats + hydro-alcoholic Aloe Vera gel extract (100 mg/kg) & $0.24 \pm 0.02 \mathrm{a}$ & $0.018 \pm 0.001^{a}$ & $25.49 \pm 4.49^{c}$ \\
\hline Starved rats + hydro-alcoholic Aloe Vera gel extract (200 mg/kg) & $0.25 \pm 0.02^{a}$ & $0.016 \pm 0.001^{a}$ & $25.65 \pm 6.04^{c}$ \\
\hline $\begin{array}{l}\text { Without starvation with hydro-alcoholic Aloe Vera gel extract } \\
(100 \mathrm{mg} / \mathrm{kg})\end{array}$ & $0.29 \pm 0.03^{a}$ & $0.017 \pm 0.001^{a}$ & $38.33 \pm 5.15 d$ \\
\hline $\begin{array}{l}\text { Without starvation with hydro-alcoholic Aloe Vera gel extract } \\
(200 \mathrm{mg} / \mathrm{kg})\end{array}$ & $0.27 \pm 0.03$ & $0.015 \pm 0.002^{a}$ & $39.83 \pm 5.77^{d}$ \\
\hline
\end{tabular}

Different letters indicate statistically significant differences $(P<0.05)$

Plasma levels of $\mathrm{Cu}, \mathrm{Zn}$ and $\mathrm{Mn}$ are shown in Table 2. Plasma levels of $\mathrm{Cu}, \mathrm{Zn}$ and $\mathrm{Mn}$ in normal control group had no significant difference with starved rats + water/ethanol and starved rats + hydro-alcoholic Aloe vera gel extract at doses 100 and $200 \mathrm{mg} / \mathrm{kg}$ groups $(P>0.05)$.

Plasma levels of vitamins $A, E$ and $C$ are shown in Table 3. Plasma levels of vitamin $A$ and $E$ in normal control group had no significant difference with starved rats + water/ethanol and starved rats + hydro-alcoholic Aloe vera gel extract in 100 and $200 \mathrm{mg} / \mathrm{kg}$ dose groups $(P>0.05)$. Plasma level of vitamin $\mathrm{C}$ significantly decreased in starved rats + water/ethanol group $(P<0.05)$. Plasma level of vitamin $C$ after treatment with hydro-alcoholic Aloe vera gel extract at doses 100 and $200 \mathrm{mg} / \mathrm{kg}$ was significantly increased $(P<0.05)$. Also, plasma level of vitamin $C$ in normal rats (without starvation) after treatment with hydro-alcoholic Aloe vera gel extract at doses 100 and $200 \mathrm{mg} / \mathrm{kg}$ was significantly increased $(P<0.05)$. 


\section{Discussion}

Blood levels of antioxidant enzymes (SOD, GPX and catalase) significantly decreased in starved rats + water/ethanol group $(P<0.05)$. Several studies have been done regarding generation of oxidative stress by starvation $[6,7,8,9]$. Food deprivation or starvation results in reduction in critical metabolic substrate. In this situation decreased glucose utilization and parallel increase in fatty acids oxidation and keton bodies production takes place. From this sense starvation could be similar to diabetes [22]. Several studies have shown starvation stimulated peroxisomal fatty acid oxidation as well as increased $\mathrm{H}_{2} \mathrm{O}_{2}$ production $[4,22]$. Furthermore, fasting stimulated mitochondrial fatty acid oxidation and subsequently increased NADH production and its influx to TCA cycle. It caused electron transport chain to be more active and finally enhanced ROS generation [3]. Sorensen and coworkers have shown $72 \mathrm{~h}$ starvation increased free radical production and changed membrane composition in rat liver [7].

Antioxidant system components act against oxidative stress in body. Antioxidant enzymes could be affected through different factors such as environmental and dietary factors [2, 22]. Effect of fasting on antioxidant enzymes is controversial. Godin and Wohaieb [22] reviewed the effect of nutritional deficiency and starvation on tissue antioxidant enzymes. They have mentioned that alteration of antioxidant enzymes in different tissues was varied during starvation. Marczuk-Krynicka et al. [5] have shown catalase and SOD activities decreased in fasted rat livers but they did not alter in GPx activity in fasted rat livers. Wasselin et al. [3] evaluated gene expression and enzyme activities involved in the response to oxidative stress. They have shown a decrease in both catalase protein and its activity level in fasted rats. SOD gene expression showed no difference between experimental groups but GPx mRNA level was varied in fasting group depending on its isoforms.
It has been previously mentioned that starvation increased production of free radical oxygen. Superoxide radical inhibited catalase and this inhibition could be prevented by SOD. SOD and catalase act synergically. Also, SOD could be inactivated by $\mathrm{H}_{2} \mathrm{O}_{2}$ [23]. Thus, increasing production of ROS and $\mathrm{H}_{2} \mathrm{O}_{2}$ during starvation could decrease SOD and catalase activities. Fasting caused body weight loss and hypoglycemia and hypoinsulinemia [3, 5, 22]. Hypoglycemia increased lipid and protein metabolism [3]. Thus, starvation results in decreased protein production and enzyme activities as well as increasing protein degeneration. Antioxidant enzymes could be affected by these factors. Also, observed changes in antioxidant enzyme activities may have a relationship with hypoinsulinemia induced by food starvation. A previous study has shown insulin treatment normalized antioxidant enzyme abnormalities in diabetic animals [22]. Moreover, another study showed diabetic and starved rats have an imbalance in antioxidant enzyme activities but insulin treatment in diabetic rats and refeeding in starved rat could improve antioxidant enzyme abnormalities [24].

Gîlcă et al. [25] have shown SOD and Gpx activities were lower in fasting group. Intracellular GSH content decreased during starvation and Gpx express GSH for its reaction, so the decrease of intracellular GSH level may result in decreased Gpx activity in starved rats [8].

Plasma levels of antioxidant enzymes (SOD, GPX and catalase) after treatment with hydro-alcoholic Aloe vera gel extract at 100 and $200 \mathrm{mg} / \mathrm{kg}$ doses were significantly increased $(P<0.05)$. Also, plasma levels of antioxidant enzymes in normal rats (without starvation) after treatment with hydro-alcoholic Aloe vera gel extract at doses 100 and 200 mg/kg were significantly increased $(P<0.05)$.

Several studies have suggested antioxidant effects of Aloe vera [13, 14, 15, 16, 17].

Our results have shown that Aloe vera treatment caused increased antioxidant enzyme activities in 
comparison with starved group. However, we observed the effect of Aloe vera gel extract on antioxidant enzyme activities was independent of dose. Studies have mainly focused on effects of Aloe vera on diabetes. Diabetes is similar to starvation in some aspects. Aloe vera treatment increased antioxidant enzyme levels in lens of diabetic group [13]. Mohamed [17] has reported Aloe vera gel extract had antioxidant effects and significantly decreased serum MDA levels. Several studies have mentioned that Aloe vera has naturally antioxidant component including phenols, flavoids, vitamin C, vitamin E and some trace elements. These antioxidant component scavenge reactive oxidant and aid in endogenous antioxidant defense $[12,26]$.

Plasma levels of $\mathrm{Cu}, \mathrm{Zn}$ and $\mathrm{Mn}$ in normal control group had no significant difference with starved rats + water/ethanol and starved rats + hydro-alcoholic Aloe vera gel extract in 100 and 200 mg/kg dose groups $(P>0.05)$.

Regarding the unchanged levels of $\mathrm{Cu}, \mathrm{Zn}$ and $\mathrm{Mn}$, it can be suggested that despite the antioxidant activity of $\mathrm{Cu}, \mathrm{Zn}$ and $\mathrm{Mn}$, these trace elements could not indicate marked responses to oxidative injuries induced by the starvation. The unchanged levels of $\mathrm{Cu}, \mathrm{Zn}$ and $\mathrm{Mn}$ in our work may be attributed to the occurrence of equilibrium between the levels of trace elements uptake and their levels in the serum and body tissues, particularly the liver storage which probably has a role in enhancing the decreased serum level of these trace elements in starved rats.

Plasma levels of vitamin A and $\mathrm{E}$ in normal control group had no significant difference with starved rats + water/ethanol and starved rats + hydro-alcoholic Aloe vera gel extract in 100 and $200 \mathrm{mg} / \mathrm{kg}$ dose groups ( $P>0.05$ ). Plasma level of vitamin $C$ significantly decreased in starved rats + water/ethanol group $(P<0.05)$. Plasma level of vitamin $C$ after treatment with hydro-alcoholic Aloe vera gel extract at doses 100 and $200 \mathrm{mg} / \mathrm{kg}$ was significantly increased ( $P<0.05)$. Also, plasma level of vitamin $C$ in normal rats(without starvation) after treatment with hydro-alcoholic Aloe vera gel extract at doses 100 and $200 \mathrm{mg} / \mathrm{kg}$ was significantly increased ( $P$ $<0.05$ ).

Berggren Söderlund et al. [27] have reported Serum level of retinol decreased after 5 days fasting and significant correlation was observed between retinol and retinol binding protein and transthyretin plasma levels. Also, Hupert et al. [28] showed increased hepatic retinol and decrease in plasma retinol during $72 \mathrm{~h}$ starvation. These results differed with our result, possibly because of longer starvation cycle.

Regarding the unchanged levels of antioxidant vitamins $A$ and $E$ on the one side and the significant decrease in serum level of vitamin $C$ on the other, it can be suggested that despite the antioxidant activity of vitamins $A$ and $E$, these vitamins could not indicate marked responses to oxidative injuries induced by the starvation. In contrast, vitamin C may play a significant role in protecting the cells from the invasion of free radicals. It can be proposed that despite cellular protective action of vitamins against oxidative stress as a result of starvation, the unchanged level of vitamins $A$ and $E$ in our work may be attributed to the occurrence of an equilibrium between the levels of vitamin uptake and their levels in the serum and body tissues, particularly the liver storage which probably has a role in enhancing the decreased serum level of these vitamins in starved rats.

Our results show vitamin C level significantly decreased in starved rats. Fukuwatari et al. [29] have shown urinary excretion of ascorbic acid was not affected by fasting, these authors have also reported liver content of water soluble vitamins decreased during starvation but blood and muscle content of water soluble vitamins were not affected during starvation. Furthermore, ascorbic acid is synthesized from hexoses including glucose in many species. Previous study has shown synthesis of ascorbic acid is impaired during starvation [30]. 
Aloe vera treatment increased antioxidants vitamin C levels in starved rats + hydro-alcoholic Aloe vera gel extract $(100 \mathrm{mg} / \mathrm{kg}$ and $200 \mathrm{mg} / \mathrm{kg}$ ) groups. Aloe vera gel extract had antioxidant effects and significantly increased serum vitamin $C$ levels. Antioxidant activities have been increased in diabetic rats by Aloe vera treatment [16]. These antioxidant components scavenge reactive oxidant and aid endogenous antioxidants defense.

In concluding, our results shown that long period starvation caused an increase in oxidative stress via impairing of antioxidant defense and Aloe vera treatment is capable of improving antioxidative defense induced by long period starvation.

\section{Authors' Contributions}

Conceived and designed the experiments: Mehdi saeb, Saeed Nazifi, Laleh Shahraki Mojahed

Performed the experiments and analyzed the data: Laleh Shahraki Mojahed, Mohammad Mohsen Mohammadi

Wrote the paper: Saeed Nazifi, Mohammad Mohsen Mohammadi

\section{Acknowledgements}

The authors would like to thank the Research Council of Shiraz University and School of Veterinary Medicine, Shiraz University for financial and technical support of this study (Grant No.71-GR-VT-5).

\section{Conflict of interest statement}

The authors declare no conflict of interest.

\section{Funding/Support}

Research Council of Shiraz University and School of Veterinary Medicine, Shiraz University

\section{References}

1. Valko M, Leibfritz D, Moncol J, Cronin MT, Mazur M, Telser J. Free radicals and antioxidants in normal physiological functions and human disease. Intern J Biochem Cell Biol, 2007; 39(1): 44-84.

2. Limón-Pacheco J, Gonsebatt ME. The role of antioxidants and antioxidant-related enzymes in protective responses to environmentally induced oxidative stress. Muta Res/Gen Toxicol Environ Mutag, 2009; 674(1): 137-147.

3. Wasselin T, Zahn S, Maho YL, Dorsselaer AV, Raclot T, Bertile F. Exacerbated oxidative stress in the fasting liver according to fuel partitioning. Proteomics, 2014; 14(16): 1905-1921.

4. Orellana $M$, Fuentes $O$, Rosenbluth $H$, Lara $M$, Valdés $E$. Modulation of rat liver peroxisomal and microsomal fatty acid oxidation by starvation. FEBS letters, 1992; 310(2): 193-196.

5. Marczuk-Krynicka D, Hryniewiecki T, Piątek J, Paluszak J. The effect of brief food withdrawal on the level of free radicals and other parameters of oxidative status in the liver. Med Sci Mon Basic Res, 2003; 9(3): BR131-BR135.

6. Crescimanno M, Armata MG, Rausa L, Gueli MC, Nicotra C, D'alessandro N. Cardiac peroxisomal enzymes and starvation. Free Radical Res Commun, 1989; 7(2): 67-72.

7. Sorensen M, Sanz A, Gomez J, Pamplona R, Portero-Otin M, Gredilla R,Barja G. Effects of fasting on oxidative stress in rat liver mitochondria. Free Rad Res, 2006; 40(4): 339-347.

8. Domenicali M, Caraceni P, Vendemiale G, Grattagliano I, Nardo B, Dall'Agata M, Altomare E (2001) Food deprivation exacerbates mitochondrial oxidative stress in rat liver exposed to ischemiareperfusion injury. J Nut, 2001; 131(1): 105-110.

9. Robinson MK, Rustum RR, Chambers EA, Rounds JD, Wilmore DW, Jacobs DO. Starvation enhances hepatic free radical release following endotoxemia. J Surg Res, 1997; 69(2): 325-330.

10. Geiger S, Kauffmann M, Le Maho Y, Robin JP,Criscuolo F. Of the importance of metabolic phases in the understanding of oxidative stress in prolonged fasting and refeeding. Physiol Biochem Zool, 2012; 85(4): 415-420.

11. Stavric B. Role of chemopreventers in human diet. Clin Biochem, 1994; 27(5): 319-332.

12. Radha MH, Laxmipriya NP. Evaluation of biological properties and clinical effectiveness of Aloe vera: A systematic review. J Trad Comp Med, 2015; 5(1): 21-26.

13. Haritha K, Ramesh B,Saralakumari D. Effect of Aloe vera gel on antioxidant enzymes in streptozotocin-induced cataractogenesis in male and female Wistar rats. J Acute Med, 2014; 4(1): 38-44.

14. Nahar T, Uddin B, Hossain S, Sikder AM, Ahmed S. Aloe vera gel protects liver from oxidative stress-induced damage in experimental rat model. J Comp Integrative Med, 2013; 10(1):4753.

15 Trivedi N, Rishi P, Soni SK. Protective role of aloe vera wine against oxidative stress induced by Salmonella infection in a murine model. Inter J Food Nut Sci, 2015; 4(1): 64-76. 
16. Ramachandraiahgari R, Somesula SR, Adi PJ, Mannur IS, Enamala M, Matcha B. Protective role of ethanolic extract of aloe vera antioxidant properties on liver and kidney of streptozotocininduced diabetic rats. Digest J Nanomat Biost, 2012; 7(1): 175184.

17. Mohamed EAK . Antidiabetic, antihypercholestermic and antioxidative effect of Aloe vera gel extract in alloxan induced diabetic rats. Aust J Basic Applied Sci, 2011; 5(11):1321-1327.

18. Cock IE,Sirdaarta J. The toxicity of Aloe barbadensis Miller juice is due to the induction of oxidative stress. Adv Environ Biol, 2011; 288-300.

19. Paglia DE, Valentine WN. Studies on the quantitative and qualitative characterization of erythrocyte glutathione peroxidase. J Lab Clin Med, 1967; 70(1):158-169.

20. Slaughter MR, O'Brien PJ. Fully-automated spectrophotometric method for measurement of antioxidant activity of catalase. Clin Biochem, 2000; 33(7): 525-534.

21. Johnson-Davis KL, Moore SJ, Owen WE, Cutler JM, Frank EL. A rapid HPLC method used to establish pediatric reference intervals for vitamins A and E. Clin Chim Acta, 2009; 405(1): 35-38.

22. Godin DV, Wohaieb SA. Nutritional deficiency, starvation, and tissue antioxidant status. Free Radical Biol Med, 1988; 5(3):165176.

23. Kono Y, Fridovich I. Superoxide radical inhibits catalase. J Biol Chem, 1982; 257(10): 5751-5754.

24. Asayama K, Hayashibe H, Dobashi K, Niitsu T, Miyao A, Kato $K$. Antioxidant enzyme status and lipid peroxidation in various tissues of diabetic and starved rats. Diabetes Res, 1989; 12(2): 85-91.

25. Gîlcă M, Soian I, Mohora M, Petec C, Muscurel C, Dinu V. The effect of fasting on the parameters of the antioxidant defence system in the blood of vegetarian human subjects. Romanian $J$ Inter Med, 2002; 41(3):283-292.

26. Malik I,Zarnigar HN. Aloe vera-A Review of its clinical effectiveness. Inter Res J Pharm, 2013; 4(8):75-79.
27. Berggren Söderlund M, Fex G, Nilsson-Ehle P. Decreasing serum concentrations of all-trans, 13-cis retinoic acids and retinol during fasting and caloric restriction. J Inter Med, 2003; 253(3): 375-380

28. Hupert J, Cunningham KN, Mobarhan S, Friedman HJ, Layden TJ. Effects of acute starvation on vitamin A status in rats. J Am College Nut, 1989; 8(6): 644-649.

29. Fukuwatari T,Yoshida E, Takahashi K, Shibata K. Effect of fasting on the urinary excretion of water-soluble vitamins in humans and rats. J Nut Sci Vitaminol, 2010; 56(1): 19-26.

30. Stirpe F, Comporti M. Regulation of ascorbic acid and of xylulose synthesis in rat-liver extracts. The effect of starvation on the enzymes of the glucuronic acid pathway. Biochem J, 1965; 95(2): 354
Publish in International Archives of Medicine

International Archives of Medicine is an open access journal publishing articles encompassing all aspects of medical science and clinical practice. IAM is considered a megajournal with independent sections on all areas of medicine. IAM is a really international journal with authors and board members from all around the world. The journal is widely indexed and classified Q2 in category Medicine. 